If this be the true explanation why the radiation of bodies deviates from Newton's law, it should follow that in the case of gases where the particles stand at a considerable distance from one another, the obstruction to interior radiation must be far less than in a solid, and consequently that the rate at which a gas radiates its heat as its temperature rises, must increase more slowly than that of a solid substance. In other words, in the case of a gas, the rate of radiation must correspond more nearly to the absolute temperature than in that of a solid; and the less the density and volume of a gas, the more nearly will its rate of radiation agree with Newton's law. The obstruction to interior radiation into space must diminish as we ascend in the atmosphere, at the outer limits of which, where there is no obstruction, the rate of radiation should be pretty nearly proportional to the absolute temperature. May not this to a certain extent be the cause why the temperature of the air diminishes as we ascend?

If the foregoing considerations be correct, it ought to follow that a reduction in the amount of heat received from the sun, owing to an increase of his distance, should tend to produce a greater lowering effect on the temperature of the air than it does on the temperature of the solid ground. Taking, therefore, into consideration, the fact that space has probably a lower temperature than $-239^{\circ}$, and that the temperature of our climate is determined by the temperature of the air, it will follow that the error of assuming that the decrease of temperature is proportional to the decrease in the intensity of the sun's heat may not be great.

In estimating the extent to which the winter temperature is lowered by a great increase in the sun's distance there is another circumstance which must be taken into account. The lowering of the temperature tends to diminish the amount of aqueous vapour contained in the air, and this in turn tends to lower the temperature by allowing the air to throw off its heat more freely into space.

JAMES CROLL

THE RUSSIAN GEOGRAPHICAL SOCIETY

$\mathrm{T} T$ is no easy matter to render an account of the pro1 ceedings and publications of the "Imperial Russian Geographical Society." So numerous are its sections, and so prolific is each of them, that to master the whole of the information yearly made available by them would be no easy task, even for a reader possessing the amount of leisure which most Russians enjoy. Some of its volumes, however, are intended merely as works of reference, books which are not meant to be read through, but which serve as useful storehouses of facts and figures. Of such a nature is the huge collection now before us of Pistsovuiya knigi, the rent-rolls, as it were, of the estates of ecclesiastical and lay proprietors of the soil in the sixteenth century. Some idea of the magnitude of the work may be gained from the fact that the second part alone of its first volume contains 1,598 large and closely printed pages. As a general rule, the publications of the Society are of no use to foreigners who are unacquainted with Russian. But there are a few exceptions, such as the monograph by Prof. Oswald Heer, of Zurich, on the fossil flora of the coal-fields of East Siberia. In I859 a rich collection of fossil plants was made in the Amur district by $F$. Schmidt, but it was burnt in the great fire of Blagoveshensk the year after. In 1862 a fresh collection was made, and submitted to Prof. Heer. The results of his investigations are given in the second division of "the geological part" of the third volume of "the physical section" of the Records (Trudi) of the "Siberian Expedition" of the Society, under the title of the "Jurassic Flora of the Irkutsk Government and the Amur Territory." The greater part of the text is in Russian. But as the descriptions are in Latin, and they are accompanied by thirty-one quarto plates, printed at Winterthur, the book is available for Western scholars. The expedition of the late A. Tchekanovsky to the Lena in I875, says the editor, F. Schmidt, in his preface, has contributed new and important additions to our knowledge of the Jurassic flora of Siberia. "The Jurassic plants collected around Bulun and Ayakit, Lower Lena, serve as a link between the Jurassic flora of South-East Siberia and the same flora of the Spitzbergen Isles, and prove the unity and comparative uniformity of the Jurassic flora over a great part of the northern hemisphere, namely from Spitzbergen to England (Yorkshire) and beyond the Lena to the Irkutsk Government and the Amur." Much valuable information about Siberia is given also in the voluminous supplements to Ritter's "Asia," "serving as a continuation of Ritter's work, based upon materials rendered available since $1832 . "$

Among the subjects treated at greatest length in the Transactions (Zapiski) of the Ethnographical Section of the Society are "The Shores of the Frozen and White Seas," "The Church Calendar of the Common People," and the "Popular Juridical Customs of the Russian Empire." The treatise on the first gives a full account of the various tribes inhabiting the inhospitable northern shores. In speaking of the Samoyeds, it may be worthy of remark, the author does not even so much as allude to the absurd explanation (dear to many English minds) of their name as meaning cannibals. Lyudoyed, in Russian (from lyudi, men, and yest', to eat), signifies a cannibal. A false analogy has resolved Samoyed into the same meaning. If it meant anything in Russian, it would mean a "selfeater," whatever that might be. Russian philologists explain it in different ways. Some, as Lerberg, consider it a Russian word, corrupted from Semgo-yed, a salmoneater. Byelyavsky says that the Samoyeds employ, in speaking of each other, a common tribal or family designation Khasovo, from Khaz, self (in Russian sam) and ovo, one (in Russian odin). From these Russian equivalents of the Samoyed words, sprang, he supposes, a designation Sam-odin or Sam-yedin. In some old documents the Samoyeds are called Suiroyadtsui, from their habit of eating raw (suiroe) meat. But there seems to be no reason for supposing that the two names have any connection. Much more probable is the surmise that the word is of Finnish origin, the land belonging to some Ugrian neighbours of the Samoyeds having been called Samoyanda or Samoyedna, from which the Russians formed the name Samoyed. The Calendar gives a detailed account of the Saints' days observed by the Russiar peasants, and of the various superstitions and rites connected with them. It begins with September, which was officially chosen as the first month at the Council of Moscow in 1342 . In ancient days March was among the Russians, as it was among the Israelites, the commencement of the new year. Its modern name, Mart, was derived from Rome through Byzantium; the heathen Slavs knew it as Sukhy, "the Dry," or Berezozol, from its effect on the bereza or birch-tree.

The volume devoted to the juridical institutions of the common people, their civil and criminal law courts, is full of interest; and the information it contains is thoroughly trustworthy, having been carefully collected and sifted by the members of a Commission appointed for the purpose in 1876 . It embraces not only the village-jurisprudence of the Russians themselves, but also that of the strangers within their gates, and the wild tribes of their outlying provinces. Ot great interest also are the numerous volumes of Reports (trudui) issued by the members of the Ethnographical-Statistical Commission appointed to explore the western provinces of Russia. The seven large volumes devoted to the southwestern governments give an exhaustive account of Little-Russia, entering into most minute detail; concerning the physical and moral character of the inhabitants of that part of the empire, between whom and the 
Great-Russians so considerable a difference exists. Vol. I. deals with the superstitions of the peasants, especially as regards witchcraft, to which subject Prof. Antonovich of Kief has devoted a long and interesting essay. According to him, the popular ideas about the subject are "not demonological, but pantheistic." And the authorities seem to have looked upon wizards and witches with some indulgence. In a hundred trials of persons accused of witchcraft in the eighteenth century, he finds scarcely any trace of such cruelty as was shown at an earlier period by British or German legal officials, or by the Inquisition in the south of Europe. Burnings were unknown. Convicted warlocks were generally mulcted in a fine paid to the Church. In the few cases in which they were punished more severely, the unusual harshness of the court was due to the fact that the complainant belonged to the class of nobles. The second volume contains a valuable collection of 146 skazki or folk-tales, 3r of which are classed as "mythical." It forms an important supplement to Rudchenko's excellent "Collection of South-Russian Tales." Vols. iii.-v. contains an immense number of folk-songs, and a list of days to which the peasants pay special attention. The sixth volume is devoted to popular jurisprudence in general and the village courts in particular, and the seventh to statistics, giving a complete account of the Little-Russians themselves, and of the rest of the population, whether of Polish, Jewish, or other extraction.

\section{TEMPERATURE OF THE SOIL DURING WINTER}

$\mathrm{T}$ E French physicists, Edmond and Henry Becquere] took advantage of the intense cold prevailing at Paris last December, to study the changes in temperature below the surface of the soil under various conditions. It is a widely-spread belief among farmers, that when protected by a layer of snow, crops sown in the autumn are effectually guarded against freezing. This opinion, howєver, must lose much of its weight in view of these late observations, which we will briefly summarise.

The observations were made by means of Becquerel's electric thermometer, which consists simply of two wires isolated by a coating of gutta percha, and soldered together at their extremities. Differences in temperature between the two places of junction cause electric currents varying in intensity with the greatness of the difference. A magnetic needle, brought under the influence of the current, registers on a dial these differences. The wires were inserted in the Jardin des Plantes at various depths varying from 5 to 60 centimetres, and observations were made from November 26 to the close of December. Frost first appeared in the Garden November 26. December 3 snow fell in abundance, and the temperature of the air sank to $-\mathrm{II}^{\circ} \mathrm{C}$. The layer of snow was 25 centimetres deep. December 10, the temperature had sunk to $-21^{\circ}$, and commenced then gradually to rise. December 15, the snow was 19 centimetres in depth.

Coming now to the observations made below the surface of the ground under the above circumstances, we find at once a striking difference between the results obtained in soil covered with grass, and those obtained below a bare surface of the ground. In soil protected by grass, before as well as after the snowfall, at all depths below that of 5 centimetres, the temperature never descended below $0^{\circ} \mathrm{C}$. Registering $3^{\circ} \cdot 5$ at the depth of 5 centimetres on November 26 , it slowly sank to $0^{\circ}$. 8 on December I4. The presence of grass would appear, then, to effectually protect the earth beneath it from freezing at the lowest temperatures attained in our climate. Quite different results, however, are yielded in the absence of grass. In this case at a depth of 5 centimetres the thermometer sank below zero on November 27. Two days later it registered $\ldots 2^{\circ} \cdot 6$.
On December 3, just before the snowfall, it reached its mininum of $-3^{\circ} 17$. After being covered with snow it registered $-0^{\circ} \cdot 8$, and later $-1^{\circ} \cdot 4$. The snow here appears to act in a certain measure as a screen against changes in temperature, but its conductive properties are still too marked to prevent these changes from being felt sensibly at a certain depth in the earth. In the case of the agriculturist, this slow conduction, when united to the still slower conductive properties of a tolerably thick layerof dead shoots of cereal crops sown in autumn may frequently insure immunity from freezing to the roots below the surface.

T. H. N.

\section{NOTES}

WE regret to have to announce the death of P. W. Schimper, the well-known Professor of Palæontology in the University of Strassburg, and of Dr. R. H. C. C. Scheffer, the amiable and accomplished director of the Botanic Garden, Buitenzorg, Java, at the early age of thirty-five. Also of two foreign entomologists -Herr Hellmuth von Kiesenwetter at Dresden, in the sixtieth year of his age, and Dr. Snellen van Vollenhoven, formerly Conservator of the Leyden Museum, one of the foremost ento. mologists of Holland, and author of "Faune Entomologique des Indes Orientales."

WiTH reference to Prof. Smyth's communication in regard to the exhibition of anrora on March I7 (NATURE, vol. xxi. p. 492), we are informed that the photographic records of the Royal Observatory, Greenwich, show that there was also magnetic disturbance on that day.

\section{DR. W. FARr has been made a C.B.}

DR. C. WILliam SIEMENs has been elected an honorary member of the American Institute of Mining Engineers.

THere has just appeared, as Vol. XII. of the Report of the United States Geological Survey of the Territories under Dr. F. V. Hayden, an important monograph on the Freshwater Rhizopods of North America by Dr. Joseph Leidy, the eminent comparative anatomist of Philadelphia. It is a well-printed quarto, and sumptuously illustrated with a series of forty-eight coloured plates. Containing the results of an investigation of materials partly collected during the prosecution of the Survey, it shows the broad scientific spirit in which the operations of Dr. Hayden's Survey were conducted. Dr. Leidy, almost elbowed out of the field of research among the fossil vertebrates of the West, where he was the earliest pioneer, has left that field in possession of his younger friends, Professors Cope and Marsh, and has betaken himself to another and very different domain of scientific research, with which he has long been familiar. To the monograph which he has now issued we hope to call attention in an early number of this journal.

A NEW School of Agriculture is to be opened, to be called the South Wiltshire and Hampshire Agricultural College, at Downton, near Salisbury, on A pril 26. Among the teaching staff will be : Prof. Wrightson for Agriculture, Prof. Church, Chemistry ; Prof. Fream, Natural History and Geology; and Prof. Sheldon, Dairy Work. Attached to the college is a mixed farm of $54^{\circ}$ acres, to be worked by the students themselves.

AT the Royal Institution on Tuesday next (April 6) Prof. Huxley will give the first of a course of two lectures on Dogs and the Problems connected with them; on Thursday (April 8) Prof. Tyndail will give the first of a course of six lectures on Light as a Mode of Moticn; on Friday evening (April 9) Prof. Huxley will give a discourse on the Coming of Age of the Origin of Species; and on Saturday (April Io) Mr. James Sully will give the first of a course of three lectures on Art and Vision. 